\title{
PENDIDIKAN KARAKTER BERBASIS PANCASILA: PAPARAN SEJARAH IDEOLOGI, IDEOLOGI PANCASILA, DAN RELEVANSINYA DI ERA DIGITAL
}

\author{
Hardiyanti \\ Fakultas Filsafat, Universitas Gadjah Mada, Yogyakarta \\ e-mail: hardiyanti@mail.ugm.ac.id
}

\begin{abstract}
This article aims to give a brief explanation in the importance of incorporating Pancasila in the education in Indonesia. Pancasila as the state ideology becomes the unifying force of inspiration for the nation, which in this case strictly means ethnic group that fundamentally has distinct cultural feature that can be traced to each other's natural state. The philosophical reflection in this article provides contemplative outlook on what is an ideology and how it materializes into some form of productivity embedded in every life of individual in the state.
\end{abstract}

Keyword:

post-truth, ideologi, and Pancasila

\section{PENDAHULUAN}

Cicero dalam May (2014, pp. 166-167) pernah berkata bahwa letak kesejahteraan sebuah negara adalah di dalam karakter setiap warga negaranya. Sepanjang sejarah, masyarakat telah mengidentifikasi kebutuhan untuk mencetak generasi dewasa mendatang yang terpelajar dan nantinya mampu mewariskan pengetahuan serta skill tersebut ke generasi selanjutnya. Sejarah telah mencatatkan bahwa jauh sebelum era sekarang yang kita kenali sebagai era digital, sistem pendidikan harus mengutamakan pembangunan karakter. Tokoh seperti Cicero dan filsuf Stoa lainnya tidak hentinya menitikberatkan pada introspeksi internal kepada sikap dan tindakan daripada skill retorik yang mampu mempengaruhi orang lain. Hal ini membuktikan bahwa untuk menjadi bagian masyarakat luas yang kontributif, seseorang harus mempunyai integritas akan dirinya dan kritis akan proses kultivasi kepribadian dan potensi diri. Dengan begitu, organisasi besar yang disebut "masyarakat" atau society akan dengan menunjukkan keunikan lewat elemen terkecilnya, yaitu anggota masyarakat, dengan properti karakter masing-masing yang proporsional. Corak masyarakat tidak harus serta-merta terus menunjukkan keseragamannya lewat shared-value yang terefleksi dalam kebudayaan, ideologi, kepercayaan dan lain sebagainya. Tetapi, individu yang terkandung di dalam kelompok masyarakat pun berhak untuk menunjukkan otonomi dirinya lewat ekspresi karakter yang masih pada level moderat, mengingat antara warga negara dan penyelenggara negara terikat di dalam sebuah kontrak sosial yang membutuhkan partisipasi aktif dan seimbang di tengah-tengah keberagaman dan keunikan setiap individu.

Pembahasan Pancasila sebagai ideologi yang akan diangkat dalam artikel ini menunjukkan beberapa fitur-fitur distinct yang dianggap penting dalam membentuk sebuah 
Gadjah Mada Journal of Humanities, Vol. 5, No. 1

konsolidasi kontrak sosial dan sekaligus pedoman pembangunan karakter nation. Dalam hal ini, Pancasila diperlakukan sebagai inti pendidikan karakter individu Indonesia dalam menangkal pengaruh radikal era digital yang salah satunya disebut hoax atau berita yang tidak benar atau tidak mempunyai sumber yang kredibel, hanya mengandalkan headline bombastis dan antara headline-konten tidak mempunyai relevansi bermakna sama sekali. Pemetaan penjelasan artikel ini akan dimulai dengan menjabarkan hakikat filosofis Pancasila hingga membuat posisinya substantif di tengah-tengah proses kontrak sosial masyarakat Indonesia. Kemudian, karakteristik akan hoaks yang invasif hingga memberi konflik batin individu dan mengganggu proses pembangunan karakter tersebut.

\section{HAKIKAT FILOSOFIS PANCASILA}

Pancasila sebagai ideologi dapat dimengerti sebagai sebuah agreement yang tercipta lewat kontrak sosial, sinergi antara "pemberi" dan "yang diberi" sangat menentukan kesuksesan eksistensi sebuah kelompok. Ini merupakan corak primordial yang terjadi di zaman pra-sejarah di mana terdapat hierarki vertikal antara pemimpin grup dan distribusi peran di masing-masing anggotanya, seperti yang mengumpulkan makanan atau yang berjaga untuk mengawasi hewan predator yang dapat mengancam keselamatan mereka. Seiring dengan berjalannya waktu, mutasi genetik lewat seleksi alam menyempurnakan berbagai potensi laten yang terkandung di dalam diri mereka seperti keinginan untuk meneruskan warisan, menjalin komunikasi yang aktif serta keinginan untuk bersama dan membangun jaringan yang lebih besar. Saat itulah dibutuhkan sebuah alat pemersatu. Sebagaimana yang diklaim oleh Dietrich (2015), social-knit yang kuat dan solid membutuhkan sesuatu yang hanya dimengerti oleh anggota di dalamnya (quasi-secret) yang juga berfungsi sebagai otoritas moral dan kontrol sikap di dalam hubungan vertikal tersebut. Ciri khas sebuah masyarakat yang dikemukakan Dietrich dapat dikatakan sangat dasar dan bahkan primordial mengingat manusia dalam teori Darwin merupakan byproduct dari proses panjang evolusi primata yang secara biologis bersifat deterministik lewat mutasi genetik yang terus berkembang dan beradaptasi di lingkungan sekitarnya.

Paparan yang mendukung Dietrich pun terkandung dalam Auguste Comte lewat observasi fenomena sosial. Tiga fase yang perkembangan masyarakat menurut Comte dalam Gane (2006) bermula dari sesuatu yang bersifat metafisis dan cenderung sulit diartikulasikan secara saintifik. Sekelompok orang tersebut tergabung dalam sebuah asosiasi yang disebut gereja, atau dalam lingkup luas adalah kelembagaan yang bersifat relijius. Kontinuitas eksistensi gereja kemudian ditantang oleh pemikiran radikal ilmiah yang dilakukan oleh figurfigur seperti Gallileo Galilei, Nicolas Copernicus atau pelaut-pelaut kuno seperti Christopher Colombus dan Ferdinand Magellan. Ketimpangan dogma yang dipercayai oleh gereja dalam injil serta yang bersifat fakta realitas berdasarkan observasi empiris dan konsistensi fakta tersebut yang mengingkari otoritas injil kemudian melahirkan gelombang perkembangan masyarakat selanjutnya yang bersifat humanis. Sifat humanistik seperti mencurahkan penghargaan terhadap potensi kriya manusia lewat seni dan budaya serta otonomi diri yang kritis semakin memojokkan dogma agama dan memberi ruang pada ilmu pengetahuan, terutama yang bersifat empiris, untuk berkembang pesat. Sehingga, dunia yang pernah mengalami revolusi panjang dalam ilmu pengetahuan sekarang pada hakikatnya berpijak kepada apa yang dahulu disebut Comte dogmatik-metafisis dan bersifat opresif pada otonomi 
Gadjah Mada Journal of Humanities, Vol. 5, No. 1

diri tetapi berdaya ikat pada anggota inferior di bawahnya. Posisi yang inferior membuat mereka tidak berdaya namun secara perlahan membangkang dari lingkaran tersebut.

\section{MENGENAI HOAKS DAN PANCASILA SEBAGAI INSTRUMEN MITIGATIF}

Menurut Fredal (2014), ada enam karakteristik hoaks yang terdiri dari:

1. Munculnya sebuah narasi hoaks adalah bentuk penipuan publik lewat sebuah saluran publikasi massal seperti siaran berita langsung/terekam, milis berantai di internet, pesan terusan dan lain sebagainya. Kesuksesannya sensasional dari narasi tersebut ditentukan oleh seberapa banyak atensi yang didapatkan,

2. klaim spektakuler yang masih bisa diragukan dan belum tentu hasil dari sebuah deduksiinduksi pemikiran,

3. hoaks yang bersifat spesifik dengan menargetkan kalangan-kalangan tertentu yang biasanya berjumlah masih atau mayoritas,

4. hoaks membutuhkan saluran relay, yang berarti narasi sensasional tidak harus bertahan tetapi cukup kuat pengaruhnya untuk memberi impresi tahan lama dengan permainan kata, alegori serta statistik semu agar terlihat meyakinkan.

Berdasarkan karakteristik tersebut, identifikasi hoaks menyentuh aspek logos (sajian logis lewat data dan analisis interpretatif dari data rekaan tersebut), ethos (bersumber pada suatu otoritas kredibel dan penggunaan diksi tepat dalam penyampaian narasi) serta pathos (yang ditunjukkan lewat sebuah pengalaman atau contoh untuk menarik simpati pendengar atau pembaca). Evaluasi kritis lewat pendekatan pemetaan retorika tersebut memungkinkan aktivitas menyoalkan kembali sebuah narasi untuk mengantarkan individu pada kejelasan sebuah situasi. Bagi kalangan awam, kejelasan elemen-elemen retorika tersebut tidak begitu penting asal suatu hal bernada sensasional, penuh dengan untaian prosa artistik yang menjebak mereka dalam efek virtual yang riil situasi bahkan sebelum melihat kondisi nyata. Detail-detail yang ada dalam sebuah narasi hoaks bersifat isolatif, karena memainkan imajinasi pembaca atau pendengar. Namun, tidak dapat dipungkiri bahwa sebenarnya esensi keberhasilan hoaks juga mengandalkan partisipasi individu secara nalar dan moral dan seluruh elemen terkait untuk memupuk narasi tersebut secara gradual (perlahan) dan perpetual (perulangan) di benak setiap individu.

Bendungan hoaks yang tidak terelakkan dalam realitas cyber Indonesia hanya dapat dimitigasi dengan berbagai upaya yang tentunya menginginkan partisipasi semua pihak untuk mewujudkan iklim damai dalam semua aspek berkehidupan. Hal yang relevan sekarang dan menjadi agenda setiap edukator Indonesia adalah penyampaian filsafati yang ringan tentang Pancasila di semua level serta asesmen secara bertahap akan upaya-upaya pendidikan karakter berbasis Pancasila. Inti dari Pancasila itu adalah menuntut kesadaran akan eksistensi lain serta merangkul perbedaan. Selain itu, sebuah pengertian akan apa itu nation dengan basis definisi historis di Indonesia hingga membentuk bangsa Indonesia masa modern sekarang perlu diagendakan ulang. Dalam hal ini, mengenai sejarah panjang perjalanan migrasi proto- dan deutro-Melayu serta akulturasi etnis Melanesia yang ada di timur serta riwayat historis kolonialisme yang panjang dengan rekam jejak monopoli dalam semua bidang seperti pendidikan, sumber daya dan represi otonomi diri. 
Gadjah Mada Journal of Humanities, Vol. 5, No. 1

Maksud dari otonomi diri itu adalah nilai intrinsik dan a priori setiap manusia yang pada hakikatnya berpotensi untuk menggapai kemajuan dan lahan bagi proses kultivasi karakter dan Pancasila sebagai benihnya. Pengenalan ulang konflik yang diakibatkan oleh segregasi kaum intelektual dan kaum nasionalis di masa sebelum kemerdekaan Indonesia yang mengakibatkan tumbuhnya sentimen antara dua kubu tersebut, sehingga menumbuhkan stimulan intelektual orang-orang muda Indonesia. Kemudian, dalam sektor pendidikan, perlu adanya pemberian tempat baru dan solid untuk gaya berpikir pendekatan historis yang komprehensif seperti menyoalkan ulang awal era digital Indonesia yang ternyata mempunyai relevansi erat dalam agenda politik Indonesia. Tuntutan persebaran cepat informasi atas pertimbangan populasi besar dan terpisah secara geografis juga mempunyai batu sandungan akibat sentimen kesukuan dan status sosial (yang berpunya-yang tidak berpunya) dengan konsekuensi lanjutan hubungan patron-klien yang tidak harmonis dalam level regional.

Mengingat Kemudahan teknologi di Era Digital sekarang, agenda ketahanan Pancasila sudah seharusnya menjadi barang tentu untuk dihidupkan kembali untuk meredakan hoaks yang memecah-belah bangsa. Jika dahulu pada zaman rezim Orde Baru ada yang disebut Pedoman Penghayatan dan Pengamalan Pancasila (P4) (Morfit, 1981), maka secara retrospektif pemerintah incumbent di masa kini seharusnya sudah sampai pada pemikiran bahwa ketahanan ideologi adalah sebuah agenda perenial dari masa ke masa. Percobaan untuk menjamin ketahanan tersebut harus terus-menerus berada dalam proses perpetual lewat perencanaan ulang, distribusi merata informasi ideologi Indonesia serta relevansinya di masa lalu dan sekarang dalam membentuk negara dan orang Indonesia. Era digital yang memungkinkan persebaran informasi dengan cepat, on demand dan dapat diakses setiap waktu seharusnya memotivasi pemerintah untuk menghidupkan kembali ideologi dan filsafat hidup orang Indonesia serta edukasi yang bersifat inter-personal yang dilakukan secara bertahap pada setiap level pendidikan, lapisan masyarakat, atau pun regional.

\section{REFLEKSI HISTORIS PANCASILA SEBAGAI BENTUK KONTRAK SOSIAL}

Pada babak selanjutnya dalam kontrak sosial setelah kemunculan gerakan positivisme ilmu pengetahuan, pengamalan relijius secara bertahap kehilangan posisi prioritasnya sebagai pengikat masyarakat. Peradaban yang semakin maju berkat revolusi ilmu pengetahuan secara tidak langsung melahirkan shared-belief baru yang secara filosofis dimaknai sebagai pedoman hidup setiap elemen masyarakat dan pemimpinnya. Sejak Perjanjian Westphalia di tahun 1648, komunitas masyarakat yang bersifat regional dan yang terikat pada kesatuan agama dan prinsip mengkristalkan eksistensi mereka menjadi sebuah sistem yang terintegrasi dan mempunyai hubungan hierarkis (inferior-superior) dan horizontal (antar masyarakat). Pijakan perjanjian tersebut merupakan ilham pertama sistem kenegaraan yang dikenal sekarang (Rowen, 1961).

Masih dalam diskursus negara yang membutuhkan alat penyatu, pergeseran paradigma yang terjadi di masa Aufklärung atau abad pencerahan semakin menuntut bentuk baku pemersatu yang prinsipal tetapi non-religi. Perang yang tadinya dibumbui perseteruan agama (perang salib, reformasi Kristen, reformasi gereja di Inggris) kini berubah menjadi perseteruan prinsip (peran ideologi). Althusser (1971, pp. 77-80) mengusung pendekatan historis tentang istilah populer ideologi lewat naratif Revolusi Prancis dengan rezim teokrasi raja Louis XVI. Sebagai antitesis dari rezim status quo yang opresif, kesatuan prinsip sekuler 
yang ditekankan pada jiwa humanis berakar pada masalah klasik perang kelas yang sebelumnya pernah terjadi di masa Romawi Kuno dan juga rezim-rezim opresif lain yang memonopoli sebuah alat pemersatu untuk agenda-agenda tertentu yang bias. Dalam retrospektif sejarah, istilah ideologi pada masa Romawi Kuno memang belum muncul, tetapi esensi penting "alat pemersatu" yang nantinya berubah istilah menjadi ideologi baru muncul setelah Perjanjian Westphalia di momentum Abad Pencerahan.

Sebagai penjabaran lanjut, Althusser (1971) meredefinisi ideologi dalam dua perspektif: ideal dan positif. Tentunya, yang membedakan kedua perspektif tersebut adalah daya fungsi yang ditawarkan melalui ideologi sebagai suatu ide, yang bersifat kosong, sekumpulan mimpi yang terkandung dalam pikiran yang lahir dari otonomi domain berpikir kritis individu atau kolektif. Dari segi positif, ideologi yang tadinya hanya sebuah mimpi kolektif kini diwujudkan sisi praktisnya yang tidak hanya sebagai pemersatu kolektif tetapi juga motor penggerak juang. Sifat positif dari sebuah ideologi yang terstruktur dan prinsipal diwujudkan ke dalam sebuah sistem yang lebih besar lagi seperti dalam sistem hukum, kebijakan publik dan konstitusi dasar.

Abad 20 merupakan "Aufklarung" bagi negara-negara pasca-kolonial yang menolak imperialisme, sistem kenegaraan monarki, feodalisme atau bentuk sistem pemerintah yang opresif, fasis dan berpihak. Indonesia merupakan salah satu negara yang berhasil melarikan diri dari bayangan monarki Belanda dan proxy pemerintahannya lewat sistem regent atau monarki elektif di beberapa tempat di Indonesia. Hal tersebut dimaksudkan pemerintah kolonial sebagai instrumen pengawasan tidak langsung dengan sistem trust-building karena aparaturnya diambil dari orang pribumi sendiri yang disebut Bupati. Preservasi sistem feodal seperti Eropa abad pertengahan di Indonesia pada konteks kolonial Indonesia dapat dilihat dalam karya Edward Douwes Dekker (Multatuli) dengan judul Max Havelaar yang bercerita tentang riwayat hidup pegawai kolonial rendahan yang idealis di Tanah Jawa dan kesaksiannya akan proxy pemerintahan Kerajaan Belanda yang opresif dan mengingkari etika imperialis Belanda yang seharusnya humanis (Zook, 2006). Belanda yang secara historis merupakan kekuatan minor dalam kancah perpolitikan dan perjalanan sejarahnya di Eropa pernah menjadi bagian koloni Prancis di abad pertengahan Eropa tepat pada masa lahirnya pemikiran humanisme Erasmus.

Ironisnya bahkan figur seperti Erasmus yang tidak berpihak dan berintegritas dalam riwayat perjalanan hidupnya (tetap menjadi Katolik sejati di tengah terpaan pemikiran reformasi Kristen dan berprinsip toleran akan perbedaan agama, dalam hal ini tentu denominasi Kristen), tidak menjadi acuan dalam menyejahterakan subjek koloni di Hindia Belanda pada saat itu. Akibatnya, kritikus sosial seperti Multatuli menuliskan naratif sejarah lewat karakter Max Havelaar dan dinamika konflik kepentingan dalam domain kepemerintahan kolonial serta ilustrasi pemandangan feodal perkebunan kopi yang idyllic dan pastoral tanah Jawa di abad 19. Makna seorang individu tidak ditonjolkan dalam masa ini. Apa yang ditonjolkan adalah kelompok elit yang dianggap menjadi representasi ideal dari segmen terkecil dalam kehidupan bermasyarakat Hindia Belanda. Hal ini mengindikasikan bahwa domain sejarah Belanda sebagai negara dan koloninya adalah dua lensa sejarah yang berbeda. Selain itu, humanisme Belanda yang sekuler dan cenderung toleran sebagai bagian dari rangkaian Renaissance fase akhir Eropa tidak secara langsung menggerakkan revolusi intelektual Indonesia pada saat memasuki abad 20 Indonesia, mengingat politik etis Theo van Deventer mendapat dukungan dari populis pro-pemerintah kolonial sebab hal tersebut berarti memberi legitimasi status quo kolonial (Vickers, 2013, p. 24). 
Gadjah Mada Journal of Humanities, Vol. 5, No. 1

Ricklefs (2001, p. 193-198) memetakan periodisasi sejarah Indonesia di dekade awal abad 20 sebagai indikator self-awareness akan identitas nasional yang unik dan distant dari opresornya, yaitu pemerintah kolonial dan aparatur yang mendapat keuntungan akibat eksploitasi massal orang pribumi (inlander). Secara bertahap, pergulatan prinsip antara kaum nasionalis dan kaum intelektual di dekade kedua abad 20 Hindia Belanda yang ditandai dengan munculnya gerakan atau organisasi progresif pribumi bersamaan dengan momentum Politik Etis yang digagas oleh van Deventer. Dalam Ricklefs (2001, p. 228), terdapat sebuah gagasan moderasi yang menjamin keseimbangan kekuasaan (power-balance) antara elemen superior pemerintahan kolonial (gubernur jenderal dan aparatnya) serta inlander yang secara relatif berpendidikan tinggi hasil didikan institusi Eropa. Power-balance seperti ini yang memupuk kesuburan gerakan intelektual Indonesia yang kebetulan bersamaan dengan semangat revolusi di Eropa yang ingin menggebrak imperialisme, monarki dan feodalisme. Contohnya yang terjadi di Rusia dengan digulingkannya Kekaisaran Rusia dan keluarga Kaisar Nikolas oleh kaum partai sosialis Bolshevik.

Berawal dari sebuah gerakan intelektual yang menitikberatkan pada aspek pendidikan, gerakan lainnya yang muncul kemudian berpindah fokus kepada penguatan identitas nasional di dekade ketiga abad 20. Masa-masa krusial di mana orang-orang inlander menginginkan kemerdekaan dan otonomi pemerintahan penuh atas tanah mereka adalah motto gerakan nasionalis yang menolak dominasi ideologis (Islamisme, Jawanisme, atau aliran kebudayaan dominan lainnya) yang berpihak dan berpotensi bias (Ricklefs, 2001). Mihardja (1950) dalam antologi esainya yang berjudul Polemik Kebudayaan pun menggaungkan hal yang sama dalam seperti Ricklefs pada masa pra-kemerdekaan Indonesia. Figur-figur intelektual yang besar melalui gerakan organisasi dekade awal abad 20 saling mengkontestasi kecenderungan ideologis dan prinsip yang seharusnya dianut oleh Indonesia. Hal ini membuktikan bahwa orang-orang seperti Sutan Takdir Alisjahbana, Armijn Pane, Radjiman Wediodiningrat serta figur lainnya yang disebutkan dalam antologi Mihardja mempunyai visi profetik akan kemerdekaan dan kebebasan setiap individu.

Nuansa optimistik opini-opini mereka untuk Indonesia (Hindia Belanda) yang berpotensi merdeka menjadi batu pijakan selanjutnya pada formulasi Pancasila sebagai ideologi negara Indonesia dan penanda kontrak sosial. Judul yang dipilih oleh Achdiat K. Mihardja, Polemik Kebudajaan, mensyaratkan keberagaman dan diversifikasi visi dan pandangan figur-figur intelektual yang sudah disebutkan untuk orang Indonesia yang berbudaya dengan integritas karakter sehingga menggariskan demarkasi kultural antara penjajah dan terjajah. Seperti yang diilustrasikan Alisjahbana dalam Mihardja sebagai berikut: "Dalam masyarakat kita, orang kurang kuat dan kurang berani mengemukakan kepentingannya. Bangunkanlah akan kesadaran kepentingan diri. Dalam masyarakat kita, orang kurang giat mengumpulkan dan memakai harta dunia. Didiklah bangsa kita mengumpulkan dan memakai harta dunia yang teruntuk segala umat" (1950, p. 27). Gaya didik barat yang digaungkan Alisjahbana adalah sebuah bukti bahwa orang Indonesia perlu menyadari otonomi diri mereka sebagai seorang individu yang terlahir dengan kesadaran dan nilai intrinsik a priori. Aspirasi Alisjahbana yang mengingkari gaya bermasyarakat feodal berarti memberi ruang pertumbuhan spiritual dan intelektual setiap individu, kemudian melemahkan visi hidup altruistik, serta cinta buta layaknya kultus seperti masyarakat kuno dengan nuansa feodal yang tidak lagi relevan dalam konteks masyarakat Indonesia pada masa itu. Perlu diingat bahwa esai antologi Achdiat K. Mihardja tercetak tiga kali yang dimulai dari tahun 1935, beberapa tahun 
Gadjah Mada Journal of Humanities, Vol. 5, No. 1

setelah Kongres Pemuda dan menjelang kemerdekaan Indonesia serta formulasi Pancasila di antara momen tersebut.

Sehingga, dapat dikatakan bahwa visi pendidikan bangsa Indonesia yang berbasis Pancasila untuk kelangsungan masa depan kontrak sosial nation sudah ada jauh sebelum Pancasila diformulasikan dan seperti dalam catatan sidang BPUPKI di tahun 1940an. Visi dan misi Pancasila sebagai ideologi dengan sendirinya menunjukkan apa yang dipetakan oleh Althusser tidak hanya sebagai "yang ideal" tetapi kurang menunjukkan sisi positivistiknya. Secara ideal, aspirasi Pancasila memang mengusung tujuan yang anti-imperialisme, antimonarki, anti-feodalisme dan juga sebuah pemikiran yang mampu mempenetrasi domain semua golongan (suku, agama dan ras). Sebagaimana hakikat dari sebuah ideologi yang mengikat dan ada daya fungsinya pada konteks dunia kontemporer, sepanjang kurun waktu nyaris 74 sejak kemerdekaan Indonesia, sisi positivistik Pancasila masih kurang terlihat dan dirasakan, terutama pada era digital yang bersamaan dengan momentum post-truth. Apa yang dimaksudkan oleh Althusser lewat istilah positivisme sebuah ideologi adalah ketika hal tersebut "mengenai" subjeknya, atau sungguh-sungguh menunjukkan fungsi kongkrit dari koleksi aspirasi-aspirasi yang disematkan dalam sebuah ideologi. Sehingga, hal tersebut akan mengingkari sisi idealis ideologi yang hanya sebuah mimpi kosong semata yang pada dasarnya tidak mempunyai fungsi selain daripada hasil proyeksi yang dikandung pikiran. Bagi seorang Marxist seperti Althusser, letak problematika dualisme mind-body problem adalah konsepsi yang berlarut-larut dalam naungan mimpi, yang hanya terjadi di dalam imajinasi individu yang berbadan. Sehingga, tidak ada dialektika yang berarti ketika apa yang dikonsepsikan tidak menunjukkan sisi praktisnya, terlebih lagi jika konsepsi tersebut adalah apa yang dimaksudkan dengan ideologi yang harusnya "menyentuh" masyarakat.

\section{PANCASILA DI ERA POST-TRUTH}

Terlebih dalam era digital dan post-truth, momen yang paling relevan adalah menyoalkan kembali aspirasi Pancasila dan mengembalikan kesadaran riil bernegara di tengah-tengah luasnya dan bebasnya bendungan akses digital. Formulasi Pancasila oleh pendiri negara ini malah semakin menunjukkan idealismenya belaka. Dekadensi fungsi Pancasila yang timpang, antara apa yang ideal dan positivistik seperti permainan tarik ulur oleh segelintir individu dengan kepentingan yang berbeda-beda. Dengan kata lain, Pancasila menggantungkan nasib pada rezim status quo. Mimpi yang dikandung Pancasila hanya sebagai alat monopoli persatuan dan jaminan loyalitas tetapi tidak mempunyai arah tujuan jelas. Berbicara mengenai era digital yang di mana terjadi pergeseran paradigma komunikasi yang lebih cepat, singkat dan efisien tentu ada keuntungan dan kerugiannya pula. Penyediaan fasilitas informasi yang terdigitalisasi memudahkan akses yang bersifat masih dan "menyentuh semua golongan", dengan kata lain bagi yang mempunyai device atau alat yang mampu mengantarkan pada informasi tersebut. Digitalisasi dokumen, memo, buku, artikel dan hal-hal yang tadinya bersifat paper-based tersedia dalam domain publik melalui laman web pemerintah dan sektor swasta terkait lainnya. Namun, perhatian utama yang tertuju sekarang dalam konteks era digital Indonesia adalah aksesibilitas internet yang cepat melalui smartphone, penggunaan media sosial yang kurang bijak serta filter informasi yang kurang memadai oleh berbagai pihak seperti pemerintah, provider media sosial dan individu yang mengaksesnya.

Pemecahan masalah yang relevan sekarang dan diharapkan dapat berjalan secara lanjut adalah bagaimana menciptakan iklim damai dan bijaksana dalam era digital Indonesia dengan 
individu yang berkarakter Pancasila. Seperti pemaparan sebelumnya tentang kilas balik ideologi, ideologi Pancasila serta fragmen historis yang terkait, letak permasalahan utama selalu tidak jauh dari dinamika masyarakat yang berada di tengah-tengah perang prinsip antara golongan intelektual yang "free-spirit" dan radikal dalam berpikir serta golongan nasionalis yang kerap menganggap remeh figur intelektual. Hal yang sama masih terjadi dalam pergulatan prinsip di era digital sekarang melalui retorika yang kadang tidak berlandaskan fakta-fakta riil tetapi cukup persuasif untuk menggiring opini publik.

Kesulitan selanjutnya terletak dalam riwayat opresif masyarakat Indonesia dengan residu feodal di masa lampau. Seperti paparan Alisjahbana yang menekankan pada otonomi diri dan ekspresi individu, hal tersebut dimaksudkan sebagai langkah awal untuk menyerap segala macam pengaruh eksternal yang ada di depan seperti melalui pendidikan, informasi terkait dan bentuk retorika lainnya. Pengukuhan otonomi diri lewat ekspresi individu merupakan alienasi positif agar tidak terseret oleh kerumunan. Pengamalan Pancasila tidak semata-mata harus seragam dengan lainnya, mengingat populasi Indonesia yang berjumlah masih dan perbedaan suku serta latar belakang budaya akibat sejarah panjang perjalanan migrasi Proto- dan Deutro-Melayu serta suku Melanesia yang kebanyakan berdiam di bagian timur Indonesia. Selain itu, dasar kewarganegaraan Indonesia yang terdiri dari properti ontologis eksistensi antara lain: yang permanen (suku) dan agama atau kepercayaan yang dianut merupakan komponen penting pembentuk "orang Indonesia". Sehingga, pembinaan karakter juga dapat dilakukan lewat ajaran warisan budaya dan pendidikan agama yang moderat dan progresif di setiap level pendidikan. Sebagai tambahan, segregasi yang tegas dan proporsional antara apa yang menjadi identitas kesukuan dan agama akan menjamin kebijaksanaan dalam bereksistensi sebagai subjek inferior sovereign.

Problematika selanjutnya yang harus menjadi konsiderasi untuk membentuk individu dengan karakter Pancasila adalah aksesibilitas mudah akan literatur sejarah. Secara singkat, pelajaran sejarah di Indonesia secara kronologis di mulai dari babak pra-sejarah, sejarah kerajaan Hindu-Buddha, masuknya Islam di Indonesia di abad ke 11, masa penjajahan Indonesia oleh bangsa Eropa serta sejarah kontemporer Indonesia hingga masa reformasi. Sebagai permulaan, banyak "bias sejarah" yang terjadi lewat pendidikan mata pelajaran sejarah di Indonesia yang hanya menekankan pada poin-poin sejarah tertentu dan hanya bersifat deskriptif dan kurang evaluatif serta kritis dalam penyampaiannya. Paparan sejarah yang "tidak jujur", terutama dalam deskripsi momen historis di abad kontemporer Indonesia seakan-akan "menghakimi" dan termonopoli oleh yang berwenang.

Hasilnya, beberapa media cyber yang secara interaktif dan menggunakan pendekatan unik dalam menyampaikan beberapa hal terkait sejarah Indonesia mulai bermunculan. Seperti contoh, akun Instagram Historia dan media lainnya yang menggunakan infografis berdasarkan informasi dari Historia atau media independen lainnya. Namun, semuanya belum terasa cukup dan terdistribusi secara merata mengingat wilayah Indonesia yang luas dan jangkauan jaringan yang belum menyentuh beberapa daerah. Pembinaan masif tenaga pengajar yang "melek" sejarah Indonesia dan menjunjung tinggi fenomena relativitas budaya merupakan langkah awal dalam mencapai proses cetak generasi Indonesia yang berkarakter Pancasila.

Frankema (2014, p. 14) mendeskripsikan bahwa di masa Hindia Belanda, terdapat minat besar bagi pemerintah kolonial untuk menguatkan pendidikan berbasis Kristen di luar pulau Jawa (Outer Islands) seperti Sulawesi bagian utara, Maluku dan berbagai pulau di Indonesia timur lewat pengiriman sekelompok misionaris Protestan ke berbagai pulau-pulau tersebut. Selain karena di tanah Jawa basis pendidikan Islam dengan gaya pesantren lebih kuat, 
Gadjah Mada Journal of Humanities, Vol. 5, No. 1

Parlemen Belanda menganggap bahwa keberadaan misionaris yang relatif banyak di pulau Jawa berpotensi untuk menciptakan konflik. Secara retrospektif, sudah terlihat bahwa pemerintahan kolonial di masa lampau lewat gagasan politik Etis van Deventer menginginkan kemerataan dalam hal penyelenggaraan pendidikan. Di masa kontemporer sekarang, distribusi merata dalam hal pendidikan dan informasi masih sulit tercapai sebagaimana yang terefleksi dalam sila kelima Pancasila.

Perhatian akan pendidikan baik di masa lampau lewat pesantren atau misionaris serta distribusi pendidikan yang relevan hari ini membutuhkan sinkronisasi efektif antara penyelenggara pendidikan, edukator dan juga bimbingan yang tersupervisi kepada bibit-bibit yang diharapkan. Pendidikan karakter adalah agreement yang sama antara sistem pesantren lewat karakteristik individu Muhammadan dan misionaris dengan etika kebajikan Kristen yang digawanginya. Namun, faktor pendidikan agama yang merefleksi sila pertama Pancasila belum cukup untuk menjadi elemen komplementer ontologis orang Indonesia yang juga beragam dari segi budaya. Sehingga, dapat dilihat bahwa diskrepansi pandangan nonmaterialistik dalam ajaran agama yang mementingkan pengamalan ketuhanan lewat teladan Utusan-Nya (Nabi Muhammad SAW dan Yesus Kristus) juga harus diimbangi lewat pengamalan dunia material lewat interaksi adil dan bajik dengan sesama manusia dan membentuk mindset yang "present" atau hadir secara jasmani di dunia ini. Sila kedua dan ketiga Pancasila secara lugas menyampaikan aspirasi kehidupan dunia materi yang penuh dengan hal konkrit dan empiris-sensoris lewat kebersamaan dan solidaritas antar umat manusia.

Sebuah hal yang tidak dapat dipungkiri adalah Pancasila secara esensial berbagi visi dan misi sama dengan pemikiran kiri (leftist thought). Althusser (1971, p. 172) sekali lagi memaparkan secara kritis sumber lahirnya konsep ideologi yang muncul menjelang Revolusi Prancis. Sebelum revolusi tersebut, ada dua kubu status quo yang setara, yaitu keluarga kerajaan (First Estate) dan petinggi gereja (Second Estate) pada saat itu. Subjek-subjek inferior di bawahnya secara tidak langsung teralienasi dan dihilangkan eksistensi ontologisnya sebagai individu. Jauh sebelum Revolusi Oktober di Rusia, semangat perjuangan kelas telah muncul di Prancis di masa abad pencerahan. Third Estate yaitu kaum proletar menengah ke bawah yang menuntut keadilan adalah kolektif yang menjadi figur primer dalam Revolusi Prancis.

Keunikan Pancasila sebagai ideologi yang pada dasarnya "kekirian" menuntut hal yang berbasis keadilan dalam hal pemerataan dan rekognisi semua golongan tanpa menciptakan perang kelas yang transparan seperti dalam kasus Revolusi Prancis dan Revolusi Oktober. Nilai ketimuran Pancasila yang mendukung harmoni seperti dalam tradisi filsafat Cina, dalam Mohisme dan Konfusianisme misalnya, memberi keseimbangan ruang gerak dalam arena pergolakan ideologi global. Secara kritis, Pancasila yang berkarakter inklusif dan mengatasi semua golongan, seperti yang diklaim Soekarno.

Jika memang strategi para populis Indonesia sekarang adalah menggiring opini publik lewat retorika persuasif, maka ada potensi besar untuk promosi alternatif Pancasila dengan menggunakan pendekatan historis-retrospektif yang juga secara filosofis bernada oriental yang mengedepankan inklusivitas umat. Terlebih lagi jika bentuk retorika seperti ini disiarkan luas dan dalam bentuk distribusi digital lewat dunia cyber. Dunia online yang tidak pernah tidur seakan-akan menjadi surga baru bagi yang haus akan informasi dan jalan pintas dari kebosanan dunia materi. Dunia cyber yang tidak pilih kasih akan bentuk individu yang berada di dalamnya seakan-akan mampu merangkul semua orang. Untuk itu, otoritas yang menyelenggarakan akses fasilitas tersebut pun dituntut tegas dalam menciptakan iklim damai dan kondusif. Pemberian contoh dalam pendidikan karakter pada dasarnya adalah hal paling penting. 
Gadjah Mada Journal of Humanities, Vol. 5, No. 1

Lantas problematika lain yang menghadang adalah strategi penyelenggara negara dalam membendung informasi tidak benar untuk masuk ke dalam ranah hidup warga negara. Menurut Mozi dalam You, Rud dan Hu (2018), sifat altruistik dalam konsep Cinta Universal yang berkaitan dengan etika inklusivitas menuntut kebersamaan dan kesinambungan, tidak hanya yang merangkul semua golongan tetapi secara luas berarti konsistensi antara apa yang konseptual dan sisi kontekstual sesuatu di ranah praktisnya. Sinergi antara pemimpin dan subjek-subjek di bawahnya adalah kunci keberhasilan sebuah tujuan komunitas, terlebih pada saat itu kondisi peperangan antar klan feodal kecil di daratan Cina. Masa yang disebut the Warring Period dan ajaran Mozi berfungsi untuk meminimalisir intensitas konflik antar klan dan keinginan untuk mengikuti perang sebagaimana salah satu inti ajaran inklusivitas termasuk juga sikap pasifis.

Contoh lain inklusivitas yang dalam artian sempit berarti kesinambungan antara konsep (ide yang terkandung) dan konteks (kandungan ide yang berdaya praktis) adalah pragmatisme dalam filsafat pendidikan John Dewey (You et al., 2018). Indoktrinasi adalah jalur masuk informasi kepada subjek-subjek yang dituju, tetapi untuk "doktrin" tersebut berjalan dibutuhkan pengertian kritis yang diinternalisasi lewat pengalaman untuk mewujudkan daya fungsi doktrin tersebut. Jika indoktrinasi yang bijak tetapi tegas adalah jalan menuju perwujudan karakter Pancasila yang tersemat dalam jiwa bangsa Indonesia, maka pendidikan moral lewat interaksi berasaskan toleransi, pengertian dasar akan relativisme budaya dan agama di ranah sosial dan cyber adalah komponen penting pendidikan karakter. Dalam progres pendidikan, konsep role model atau teladan yang diharapkan ada dalam diri seorang pemimpin adalah ekspresi dari aspirasi kolektif, yang dalam hal ini adalah Pancasila sebagai pedoman hidup dan landasan hukum Indonesia. Kemudian, subjek-subjek di bawahnya menangkap sebuah impresi yang bernilai positif (dan juga negatif) dan secara tidak langsung mempengaruhi opini publik. Maka dari itu, perhatian akan kebijaksanaan seorang pemimpin dalam konsep kepemimpinan Mozi serta Dewey yang menekankan pada indoktrinasi yang berasal dari sebuah kuasa otoritatif semakin menunjukkan relevansinya untuk diangkat dalam sebuah diskursus di masa sekarang.

\section{KONDISI SPIRITUAL MASYARAKAT INDONESIA DALAM DUNIA CYBER}

Di masa sekarang, pemimpin-pemimpin yang ada di level paling terendah hingga tertinggi masih kurang menunjukkan sikap kepimpinan yang bijak, kritis, adil, evaluatif dan terutama yang tidak berpihak. Iklim politik Indonesia yang terpolarisasi justru mengarah pada jalan kemunduran. Identitas kesukuan dan ras yang juga menggandeng kepercayaan atau agama sebagai bundling identitas menjadi preteks solidaritas untuk membangun sebuah peradaban. Hal ini berbanding terbalik dan kontra terhadap argumen Perjanjian Westphalia sebagai titik pijakan sebuah konsep negara. Pada dasarnya dalam nuansa klasik kedaulatan negara yang dicetuskan dalam Perjanjian Westphalia, status kewarganegaraan yang terunifikasi didapatkan dengan menciptakan hegemoni aspirasi atau harapan dalam sebuah kelompok masyarakat yang disetujui hingga segmen-segmen terkecilnya untuk menggeser posisi tribalisme yang secara impulsif justru menonjolkan "keunikan" kultur dan tidak efisien untuk memerangi perbedaan. Konsep kewarganegaraan pun telah mengalami proses pergeseran paradigma panjang yang tadinya berakar dari sikap tribalis-religius dan homogen hingga yang sekarang dikenal sebagai warga negara yang melepaskan kepentingan pribadi (rasial, kultural, 
Gadjah Mada Journal of Humanities, Vol. 5, No. 1

religius) untuk berpartisipasi aktif dengan penyelenggara negara dalam sebuah kontrak sosial yang berkepanjangan. Dengan kata lain, antara Indonesia dan Pancasila terdapat relasi necessary-contingency, yaitu, perlunya untuk menghadirkan state sebelum nation-building yang diagendakan dalam Pancasila (Newton \& Van Deth, 2005, pp. 12-13).

Iklim politik Indonesia sekarang di tengah era digital dan post-truth pun memberi dampak mendalam yang menguji sikap kepemimpinan serta karakter orang Indonesia. Era digital yang dimulai dari perkembangan internet yang memudahkan jangkauan jaringan luas untuk penyebaran informasi, lahirnya WWW (World Wide Web) dan kemudian smartphone serta media sosial terbilang cepat dan pesat di Indonesia. Menurut Hill dan Sen (1997), gagasan internet sudah menjadi wacana nasional di masa Orde Baru oleh Kementerian Pertahanan dan juga figur seperti B. J. Habibie. Kepopuleran Internet yang tidak terbendung ikut mempengaruhi mindset beberapa petinggi pemerintahan di era tersebut untuk melakukan investasi skala besar untuk perkembangan internet di Indonesia. Agenda investasi Internet di dekade akhir abad 20 tersebut adalah untuk menguatkan semangat nasionalisme dan patriotisme di Indonesia, tentunya yang masih dalam pengawasan ketat lembaga sensor pemerintah.

Walaupun Iklim politik Indonesia di bawah rezim yang menuntut konten bersifat politik untuk menguatkan nasionalisme dan patriotisme, Internet di masa awalnya mendapat respon positif yang diindikasikan dengan beredarnya warung internet (warnet) dan kontenkonten lain yang terdigitalisasi seperti koran dan majalah. Selanjutnya, Orde Baru menjadi titik berangkat argumen retrospektif pertumbuhan Internet di Indonesia. Internet dan peredaran informasi pun sudah menjadi bumerang baik bagi pemerintah dan juga masyarakat. Sebagai permulaan, lansiran lanjut Hill dan Sen (1997, p. 67) tentang Internet adalah distribusi konten untuk penguatan karakter nasionalisme dan patriotisme bangsa lewat Hankam-net untuk meminimalisir krisis kepercayaan yang melanda rezim akibat dampak masif globalisasi. Jalur masuk investasi besar ini diajukan oleh B. J. Habibie di tahun 80an yang pada saat itu menjabat sebagai Menteri Riset dan Teknologi. Proyek yang mengundang akademisi dari berbagai universitas besar seperti Institut Teknologi Bandung (ITB), Institut Teknologi Surabaya (ITS), Universitas Indonesia (UI) serta Universitas Gadjah Mada (UGM) menghasilkan koneksi interuniversitas yang disebut UniNet. Proyek tersebut merupakan visi besar Habibie dalam memperkenalkan konsep Internet dan persebaran informasi yang bersifat akademik di kalangan akademisi. Hal tersebut memberi kesempatan bagi akademisi di universitasuniversitas tersebut untuk secara aktif berpartisipasi dalam perkembangan IPTEK di Indonesia. Selain itu, walaupun UniNet merupakan prototipe bagi proyek Internet berbasis akademik selanjutnya, hal tersebut menunjukkan bahwa Internet dan sebaran informasi tidak hanya berkutat pada aktivitas yang bernuansa propaganda politik mengingat pemimpin rezim pada masa itu adalah cetakan generasi pejuang anti-Barat.

Namun, tidak dapat dipungkiri bahwa persaingan laten antara kubu akademisiintelektual dan kubu nasionalis-politikus masih terus hadir dari waktu ke waktu seiring dengan pergantian rezim. Warisan kekhawatiran akan globalisasi yang digaungkan Onno W. Purbo (Hill \& Sen, 1997, p. 67) yang mengancam integritas nasionalisme dan patriotisme Indonesia kembali menjadi wacana dalam perpolitikan Indonesia hari ini. Media sosial yang sekarang penuh dengan konten dari berbagai tema serta dihadirkan dengan berbagai macam tujuan pula memberi banyak opsi penikmat cyber. Komunitas baru yang tumbuh lewat media sosial lewat grup atau obrolan dengan beberapa anggota di dalamnya memungkinkan kesempatan pertukaran diskusi baru yang lebih persuasif. Komunitas dalam bentuk grup Facebook atau 
WhatsApp menjaring berbagai individu dengan minat khusus untuk tergabung di dalamnya. Lembaga sensor pemerintah Indonesia yang terbilang bebas di era reformasi ini tidak mampu membendung arus informasi hasil terusan (forwarded) dari berbagai pengguna. Di satu sisi, kurangnya demarkasi jelas antara domain publik-pribadi dalam media sosial tidak memungkinkan lembaga sensor pemerintah untuk menyaring informasi-informasi tersebut. Pergeseran fungsi media sosial dari hal yang bersifat pribadi seperti pembuatan profil publik, menjalin pertemanan dan memudahkan komunikasi jarak jauh yang interaktif dibandingkan layanan email dan surat-menyurat. Tuntutan tambahan fitur pada kasus Facebook dan WhatsApp berakar pada refleksi dinamika interaksi dunia nyata yang pada hakikatnya harus terkoneksi satu sama lainnya. Dalam hal ini, Jordan (2015) menyatakan bahwa media sosial seperti Facebook, WhatsApp, atau layanan Google dibuat untuk merefleksikan sebuah alienasi diri, akomodasi persona baru individu dan dengan fitur grouping yang ada, menjadi alienasi kolektif. Keinginan alienasi pun menuntut rekognisi eksistensi dengan cara memunculkan informasi tersebut di domain publik, atau hal-hal yang dapat dilihat dan dibaca ketika profil atau sebuah laman terkait dibuka. Filterisasi konten seperti dalam fitur dalam opsi "publik" atau "hanya teman" dalam Facebook mempengaruhi algoritma "big data" yang mengendap dalam server utama Facebook. Sehingga, setiap kali ada informasi yang dibagikan dalam laman pribadi Facebook, algoritma tersebut akan mempelajari pola dan bentuk informasi yang memungkinkan konten relevan muncul dalam lini masa seseorang. Informasi "clickbait" yang kerap kali berisi berita hoaks.

Berita-berita di media sosial baik itu benar atau salah, seringkali menjadi viral. Semakin "heboh" dan spektakuler sebuah narasi jurnalistik tersebut, hal tersebut semakin berpotensi untuk dibagikan ke banyak orang dan mendapat visibilitas luas. Relevansinya dalam konteks politik Indonesia sekarang adalah apa yang terjadi sepanjang musim kampanye pemilihan presiden dan anggota legislatif pada April 2019. Awal tahun 2019 yang semakin terpolarisasi menyebabkan orang-orang termotivasi untuk membagikan bentuk posting media sosial sebagai bentuk dukungan mereka kepada kandidat calon legislatif atau presiden pilihan mereka. Sebagai tambahan, adanya potensi ujaran kebencian dibalik dukungan kepada kandidat pilihan mereka.

Selain itu, narasi palsu akan kesetiaan terhadap Pancasila serta mana kandidat yang berkarakter "Pancasilais" dan mana yang bukan. Hal ini berdampak pada persebaran yang luwes berita-berita hoaks dengan headline sensasional yang dengan sekali klik mudah dibagikan dan tersirkulasi secara luas. Dampak yang mengikuti selanjutnya adalah reputasi yang tercemar dan menyudutkan kandidat tertentu sekalipun berita-berita tersebut dengan mudah pula ditarik kembali dari orbit media sosial. Populasi pengguna media sosial yang terbilang masif di Indonesia memberikan tantangan bagi otoritas cyber dalam menangkal troll atau akun-akun dari pengguna fiktif yang tujuannya hanya untuk menciptakan kekacauan massal di laman media sosial dan kemudian menggiring opini publik dengan menekankan pada aspek pathos. Ironisnya, troll terkadang dijalankan oleh pengguna hidup yang bersembunyi dibalik username atau dikendalikan oleh bot (singkatan dari robot) yang mempelajari sintaksis, pola posting yang muncul akibat fenomena "big data". Sehingga, troll yang dikendalikan oleh bot dengan algoritma khusus yang kompleks dan canggih terlihat seakan-akan user nyata karena struktur bahasa yang mereka gunakan menyerupai manusia nyata yang mampu berinteraksi dengan user lainnya di dunia cyber.

Fenomena troll seperti ini adalah bagian yang tidak terpisahkan dari era post-truth dan digital sekarang. Dengan adanya troll sebagai pelengkap retorika yang ada di dunia nyata, 
Gadjah Mada Journal of Humanities, Vol. 5, No. 1

informasi-informasi yang beredar dirasakan semakin kredibel akibat pengulangan. Hal yang tidak dapat dipungkiri lainnya adalah kekuatan retorika yang menyentuh dan persuasif dan narasi-narasi yang memenuhi aspek logos, pathos, dan ethos yang menyentuh kesadaran individu. Di tengah kekacauan, ketidakpercayaan satu pihak dengan pihak lainnya kemudian menciptakan polarisasi iklim politik yang berpihak dan mendiversifikasikan "opsi" bagi segelintir individu. Kurangnya kontrol informasi yang ketat dari otoritas dan juga kepentingan ekonomi skala besar bagi vendor media sosial membuat masyarakat terjebak dalam aliran informasi yang tidak terbendung dan pemerintah dengan kuasa yang relatif terbatas. Kebebasan berekspresi atas dasar kemanusiaan dengan otonomi dirinya serta kewajiban semu "berbagi" sebagai makhluk sosial hanyalah beberapa faktor yang memicu impuls individu cyber di media sosial. Troll artifisial Internet yang memanfaatkan momentum untuk menyebar provokasi, ujaran kebencian, memanaskan suasana politik untuk memecah fokus dan integritas berkebangsaan.

\section{KESIMPULAN}

Di era digital seperti saat ini, kehidupan lebih menjadi terkoneksi dan menghilangkan demarkasi antara ranah pribadi dan publik semakin memudahkan persebaran hoaks. Tuntutan produktivitas yang menekan jurnalisme di setiap negara juga ikut memberi celah hoaks untuk berkembang pesat. Tanpa perlu penjelasan lebih lanjut, hoaks adalah berita atau cerita yang terkesan kredibel, benar bahkan faktual dengan komposisi retorika yang berfungsi untuk menggiring opini publik atau menciptakan perasaan tidak percaya ke beberapa pihak. Inti penting sebuah hoaks tidak hanya gambar atau cuplikan video yang dipalsukan, tetapi juga berita yang mengikutinya. Fredal (2014) mengutip satiris Inggris Jonathan Swift, "Happiness is the perpetual possession of being deceived." atau "kebahagiaan adalah apa yang dimiliki oleh orangorang yang tertipu". Dengan kata lain, sesuatu yang memicu perasaan bahagia sekali pun patut dipertanyakan asal-usulnya sebab sebuah kebahagiaan tidak datang begitu saja dan ironisnya, jalan sebuah kebahagiaan diusung oleh langkah-langkah penderitaan. Orang Indonesia yang mendambakan kebahagiaan dan sesuatu yang baru dengan mudahnya terseret dan larut dalam retorika publik yang kerap tidak benar adanya. Ini bukan berarti Pancasila sebagai ideologi dan dasar negara menjadi barang absolut yang permanen. Benar adanya akan esensi permanen Pancasila. Namun, karakter individu Indonesia-lah yang patut menjadi tenaga pendorong spiritual dan intelektual untuk memberi pemaknaan yang tepat di setiap zaman terhadap Pancasila.

Untuk itu, perlu langkah-langkah radikal dalam mencetak warga negara yang terpelajar dan maju seperti yang tertera dalam sila kelima. Pendidikan yang adil dan tidak memandang adalah salah satu bentuk revolusi mental dengan nilai return investasi yang besar. Walaupun terdengar counter-intutitive, moderasi diperlukan dalam pendidikan keagamaan yang seimbang dengan mengajarkan bahwa adanya divisi domain materi dan non-materi yang tidak pada face value saling mempengaruhi. Seperti halnya dogma agama yang konseptual serta pengamalannya yang bersifat kontekstual perlu diingatkan dalam diversitas negara Indonesia. Selain itu, pendekatan personal yang terefleksi dalam pembinaan masif yang bersifat wajib dapat dilakukan untuk menumbuhkan kontrol diri dan kebijaksanaan dalam berteknologi di berbagai level seperti korporasi, pemerintahan, pendidikan dan domain lainnya yang di mana kongregasi bisa ditemukan. Sebab mentalitas "kebersamaan" adalah faktor kerentanan 
Gadjah Mada Journal of Humanities, Vol. 5, No. 1

integritas diri yang dapat berakibat fatal pada proses decision-making dan otonomi diri. Soft-skill yang value-laden, interaktif dan sesuai pada porsinya di level pendidikan menengah mengenai relativitas budaya secara konstan dan kontinu untuk menanamkan pengertian berbudaya. Era digital yang semakin berkembang pesat memungkinkan informasi beredar secara masif mampu memberikan efek dukungan atas upaya-upaya pengenalan soft-skill dan berpotensi untuk menyatukan semua kalangan.

Ideologi pada face value adalah alat pemersatu, penanda shared-value dalam komunitas dinamis inter-subjektif tiap nation yang terdiri dari segmen agama, kultur, usia dan latar belakang pendidikan. Sayangnya, Pancasila sebagai ideologi malah mendapat penggandaan fungsi menjadi instrumen moral yang menyudutkan kelompok dan melahirkan prasangka yang memecah-belah. Perlu diingatkan bahwa hal-hal yang bahkan mendapat status formal sebagai institusi seperti sistem kepercayaan, agama atau ideologi pada hakikatnya adalah bukan sebagai sumber moral jika memang visi dan misi sebuah negara adalah mengakomodasi setidaknya bentuk perbedaan di tengah persatuan. Individu pada level personal justru adalah agen moral yang bijak, rasional dan berkesadaran. Pengaruh eksternal yang masif dan perpetual seperti Internet dan media sosial adalah godaan dan tantangan besar yang menjanjikan validasi eksistensi dan dorongan ego. Manusia Indonesia yang berkarakter adalah yang "Pancasilais" sehingga menegasikan "yang lain" yang menurut kelompok lainnya tidak "Pancasilais" sebagai manusia Indonesia yang tidak berkarakter. Label validasi Pancasilais ini adalah konsekuensi dari distribusi tidak terbatas melalui platform media sosial itu sendiri dan pendidikan yang kurang bijak hingga menciptakan kultus kepribadian dangkal karena pendidikan dan pembinaan Pancasila yang hanya pada level superfisial.

Untuk itu, penting bagi pemangku kebijakan pendidikan di Indonesia untuk mengagas rencana pendidikan Pancasila yang tidak hanya teoritis tetapi juga menaikkan aspek praktisnya. Pendidikan yang praktis dapat diciptakan melalui material eksemplifikasi subtil (subtle exemplification) yang dibungkus dalam narasi retorika yang tepat dan memenuhi aspek pathos, logos, dan ethos. Selain itu, pengingat konstan atas peran keluarga sebagai tahap pertama pengenalan kontrak sosial untuk individu yang berasaskan similaritas biologis sebelum memasuki kesadaran akan similaritas sosiologis, kultur dan pada akhirnya similaritas weltanschaaung, yakni, dari apa yang dititahkan oleh ideologi atau filosofi hidup negara.

\section{DAFTAR PUSTAKA}

Althusser, L. (1971). On the Reproduction of Capitalism: Ideology and Ideological State Apparatuses (G. M. Goshgarian, trans.). London: Verso.

Dietrich, E. (2015). Excellent Beauty: The Naturalness of Religion and the Unnaturalness of The World. New York: Columbia University Press.

Frankema, E. (2014). Why was the Dutch legacy so poor? Educational development in the Netherlands Indies, 1871-1942 (No. 54). Utrecht. Retrieved from www.cgeh.nl/working-paper-series/

Fredal, J. (2014). The Perennial Pleasures of the Hoax. Philosophy \& Rhetoric, 47(1), 73-97. https://doi.org/10.5325/philrhet.47.1.0073 
Gadjah Mada Journal of Humanities, Vol. 5, No. 1

Gane, M. (2006). Auguste Comte. London: Routledge.

Hill, D. T., \& Sen, K. (1997). Wiring the Warung to Global Gateways: The Internet in Indonesia. Indonesia, 63, 67-89. https://doi.org/10.2307/3351511

Jordan, T. (2015). Information Politics: Liberation and Exploitation in the Digital Society. London: Pluto Press. https://doi.org/10.2307/j.ctt183p2xf.11

May, J. M. (2014). Trials of Character: The Eloquence of Ciceronian Ethos. Chapel Hill: UNC Press Books.

Mihardja, A. (1950). Polemik Kebudajaan (3rd ed.). Jakarta: Balai Pustaka.

Morfit, M. (1981). Pancasila: The Indonesian State Ideology According to the New Order Government. Asian Survery, 21(838-851).

Newton, K., \& Van Deth, J. W. (2005). Foundations of Comparative Politics: Democracies of the Modern World. Cambridge: Cambridge University Press.

Ricklefs, M. C. (2001). A History of Modern Indonesia Since c.1200 (3rd ed.). Hampshire: Pallgrave.

Rowen, H. H. (1961). The Peace of Westphalia Revisited. The Journal of Modern History, 33(1), 5356. Retrieved from https://www.jstor.org/stable/1876476

Vickers, A. (2013). A History of Modern Indonesia (2nd ed.). Cambridge: Cambridge University Press.

You, Z., Rud, A. G., \& Hu, Y. (2018). The Philosophy of Chinese Moral Education: A History. New York: Pallgrave.

Zook, D. C. (2006). Searching for Max Havelaar: Multatuli, Colonial History, and the Confusion of Empire. MLN: Comparative Literature, 121(5), 1169-1189. Retrieved from https://www.jstor.org/stable/4490766 